\title{
Constructing the Computable General Equilibrium to Analyse the Impact of Goods and Services Tax on Government Revenue and Targeted Household of M40 and B40 in Malaysia
}

\author{
Suriyani Saidi' ${ }^{1}$, Mukaramah Harun ${ }^{2}$, and Norrazman Zaiha Zainol ${ }^{\mathbf{3}}$ \\ School of Economics, Finance and Banking, Universiti Utara Malaysia (UUM), Sintok \\ Kedah, Malaysia ${ }^{1,2}$; Universiti Malaysia Perlis (UNIMAP) Perlis, Malaysia ${ }^{3}$ \\ suri_1402@yahoo.com ${ }^{1}$, mukaramah@uum.edu.my ${ }^{2}$, razman.pe@gmail.com ${ }^{3}$
}

\begin{abstract}
Computable general equilibrium (CGE) models have been widely used in economic policy analysis in recent years. The selection of the model is based on the CGE model's ability to see the effects on sectors, household groups, governments, and even able to see the overall economic impact for a time period. In Malaysia, the issues arise from the impact of policies analysed in the CGE modelling framework have been constrained in part by the completion of a Social Accounting Matrix (SAM). The main purpose of this paper is to propose a new Malaysian CGE model framework to analyse the impact of implementation of GST on government revenue and welfare of targeted household groups of B40 and M40 in Malaysia. The CGE model developed in the present paper is based on more recent data in Malaysian SAM (2014). Then the data was modified to suit with Malaysian CGE for GST, namely MYGST_CGE model. This paper describes the structure of MYGST_CGE, with 33 activities, 33 commodities, 7 types of labour, and 7 categories of household groups were constructed. The CGE utilized in the present study can be applied to answer questions concerning whether GST implementation would have the trade-off between government revenue and the targeted groups by taking into account the elements of GST such as standard-rate, zero-rate and exempted rate. For the purpose of policy analysis, simulation exercises are conducted using the multi-sectoral, multifactorial and multi-households approach. Based on the proposed framework model review, the instruments used for measurement of effectiveness and welfare were C-efficiency ratio, regressive, progressive, equivalent variation and simulations. The paper will give an opportunity for future research work in a related area.
\end{abstract}

Keywords: goods and services tax (GST), government revenue, household welfare, computable general equilibrium (CGE)

\section{INTRODUCTION}

Tax policy plays an important role in the economy through its impact on efficiency and equity. In the context of taxation economics, the efficiency refers to how effective and efficient the tax collection system is and has had a good impact on economic growth. Equity is the concept of justice in the distribution of income and welfare to the lower income group in particular.

In Malaysia, the implementation of Goods and Services Tax (GST) is a very hot issue to date. While it is still new, some people question the need for this tax 
reform. According to the policy, GST is very efficient in tax collection, but it does not go eliminate the consequences that should not be happening especially to consumers. In prioritizing the country's revenue to boost national growth, one of the best ways is to increase efficiency in the tax collection system. Tamaoka (1994), Gale \& Rohaly (2002), Kearney (2003) and Brendon (2013) have noted that most countries that expand their consumption tax base will experience the trade-off between efficiency and equity based on economic structure and policy respectively.

Before implementing a policy reform, the government is thinking of a fair concept that not only provides efficient tax in collecting revenue but also increasing the welfare of consumers, especially the targeted groups of B40 and M40. According to the report of the Unit Perancang Ekonomi (2015), the highest 20 per cent household group (T20) has an average monthly income of RM14,305. While the average monthly income for the 40 per cent moderate household group (M40) is RM5,662 and the average monthly income for the lowest 40 per cent household group (B40) is RM2,537. It is clear that 80 per cent of households has income below the national average of household income of RM6,141. The B40 Group is clearly facing the rise in the cost of living. Their average income of RM2,537 was lower than the average monthly household expenditure of RM3,578.

In the meantime, if the M40s are not properly addressed they will also face the burden of the rising cost of living. They will be in the group who are forced to continue to struggle for life. They are stuck among the B40 who may obtain a lot of help in the form of income transfer from the government such as subsidies, Bantuan Rakyat 1Malaysia (BRIM). Meanwhile, the T20s are getting richer because they enjoy equal tax rates for all goods and services, even enjoying tax exemptions and zero-rated tax. Increasing the wealth of the T20 groups will put pressure on raising the prices of goods and services due to increased demand for essential goods.

We should emphasize the issue of impact on government revenue and household income. The more appropriate approach of the study method is the CGE model. The CGE model is used because it has a set of similarities that have relationships between different variables. Frameworks undertook by CGE is through a simulation that interacts between economic agents and markets. Specific emphasis on the impact of the efficiency of GST in revenue collection and the contribution to decrease the budget deficit. While the equity issues on medium and low-income households will be measured using the welfare-related instruments such as regressivity or progressivity and equivalent variation. All the measurements were based on simulations results.

In the steps of building a CGE model, the SAM schedule is required as one of the key input components. The households are categorized into groups of three 
income groups, high (T20), moderate (M40) and low (B40) as well as urban and rural areas. Using the SAM table, which has an overview of the overall economic structure of the CGE model, makes this model more realistic. In addition, the elasticity factor of the Constant Elasticity of Substitution (CES) and Constant Elasticity of Transformation (CET) equations are calibrated to make this model balanced.

Therefore, the study needs to be done to determine whether the impacts will have a positive or negative impact and to perform improvements for Malaysia to be in a strong fiscal position and able to cope with global economic challenges.

\section{LITERATURE REVIEW}

Empirical studies also play an important role in a study. In Malaysia, an empirical study on GST is very limited. Often the study of the level of readiness and acceptance of the public on GST through econometric analysis has been noted. There was a study about the impact of GST using Input-Output analysis Hassan, Saari, Utit, Hassan, \& Mukaramah-Harun (2016). The focus of their study is to estimate the impact of GST on the cost of production of goods and services and costs of living in a household. The input-output price model has been developed with modifications to take about three different tax rates i.e. standardrated supplies, zero-rated supplies and exempted supplies.

However, internationally, studies on GST by using CGE analysis have long been a researcher's concern. Most of their studies emphasize the impact of welfare from various angles such as the impact on rural households, urban poor and lowincome workers. Their analysis used SAM as a tool to CGE analysis and simulations to measure the impacts with the instruments of regressivity, progressivity, income equality, unemployment, poverty, cost of living and income distribution.

Levin \& Sayeed, (2014) and Sajadifar, Khiabani, \& Arakelyan (2012) have found that the standardized rate on all goods and services has made welfare declined. This result was also found in Devarajan, J.D., Go, Robinson, \& Sinko (1997). Besides that, Rege (2002), Kearney (2003) and Go et al. (2005) have found that welfare loss occurs mostly in the agriculture sector and zero-rated goods and exempted goods need to be broadened in GST. While Bye, Strøm, \& Àvitsland, (2003) have found that the non-uniform tax rate gives welfare loss compared to the uniform tax rate.

In the issues of government revenue, there were few studies done. Most of the issues been analysed in econometrics method. In the CGE analysis, Bye et al. (2003) have mentioned about positive impact from the GST implementation in revenue and Kearney (2003) has also found the same finding and suggested the need to make an adjustment rate and improvise on zero-rated goods to balance with the welfare of household. The studies that have been conducted are based 
only on the efficiency of the current rate rather than the analysis based on the simulation to see the changes happen within efficiency and equity in different rate and approaches in GST.

Whereas the issue of competition effects in international trade and national outcomes was also studied and among others was Devarajan \& Robinson (2002) and NCAER (2009). The impact on macroeconomics was also touched by Frankel et al. (1991), Ajakaiye (1999), Lledo (2005), Giesecke \& Tran (2009) and Saira, Ahmed, \& Ahsan (2010). However, issues such as poverty eradication, inflation, government revenue and zero-rate in the GST concept are still under consideration.

In GST impact studies, most of the issues on welfare impact have been done. The studies differed in the way CGE was captured. Some studies combine the CGE and micro-simulations to see the impact of VAT on equality. This study was done by (Avitsland \& Aasness, 2004) in Norway. However, these models often assume unchanged prices producers, income before taxes, wealth and transfers and thus can miss valuable information because of the model are partial equilibrium.

There are also studies of CGE in the dynamic analysis by Okyere \& Bhattarai (2005) and Erero (2015), where they want to see the impact of CGE. They have presented a study on the impact of GST on household welfare in various sectors and economic growth for Ghana through dynamic CGE. They have seen both effects and determined whether they have any difference. Results for the dynamic model are more favourable with issue positively affected by the shocks because the time factor is taken into account.

Interestingly, this study incorporates the issue of GST impact on government revenue and the welfare of the lower and middle-income groups through various measurements. From this analysis, we can see the trade-off between both and if so, which components will be affected by GST. Households data taken from the Department of Statistics Malaysia will be classified into income groups. These data are calibrated into the table of social accounting matrix (SAM 2014). The performance of revenue collection in GST measured using the most frequently used tool is the C-Efficiency Ratio-defined as the ratio of the VAT revenue to consumption divided by the standard tax rate that formerly done by Keen \& Lockwood (2010) and Acharya (2016). To see in detail of the equity of GST, progressive or regressive and welfare impact factors will be analysed.

\section{RESEARCH METHODS}

The CGE model is a numerical approach involving a simulation process between macro and microeconomic interactions in the economy. These interactions are important in the economy to illustrate the effects of household, 
government and multi-sectors issues. The CGE model is an empirical basis for policy analysis because of its ability to evaluate theoretical and empirical effects.

In order to have a complete set of model, there are a few steps to follows. Firstly, we need to build the social accounting matrix (SAM). Since the Department of Statistics Malaysia (DOSM) recently published their SAM for the year 2014, we modified it based on the study objectives.

Secondly, from the modification of SAM table, CGE analysis will be made based on simulations. In obtaining good policy simulation decisions, the selection factor for parameters in the form of functions is important. In the simulation analysis of a policy, a single parameter or external variables will be changed and the new balance will be calculated. Then, a comparison between the new balance and the benchmark equilibrium will provide information about policy changes caused by economic variables. Finally, the results must be interpreted based on the theoretical model of an economy.

The study uses the Malaysian CGE model for GST, namely MYGST_CGE. The model developed is based on Lofgren et al. (2002). MYGST_CGE is capable of taking into account a broader set of tax instruments. For the purpose of policy analysis, simulation exercises are conducted using the multi-sectors, multi-factors, and multi-households computable general equilibrium (CGE) model calibrated to the 2014 social accounting matrix (SAM) of the Malaysian economy.

The macro MYSAM (see table 1) and micro MYSAM were constructed using Malaysian SAM 2014 published by DOSM and we modified and calibrated it to suit MYGST_CGE model. The additional data were gathered from national accounts (2014), the government budget account (2014), and the balance of payments accounts from the National Bank of Malaysia. The constructed MYSAM distinguishes 33 activities, 33 commodities, 7 types of labour, 7 categories of households, including rural and urban area, and non-citizen residents.

The specifications in this model also followed on Lofgren et al (2002) model by IFFRI and some adjustments in the input to fit MYGST_CGE model. This model allows three types of commodities, which are domestic goods, import and export. The equations below show the overall framework in the model of MYGST_CGE incorporates all flows in the economy.

\section{Price Block}

Import Price

Import price is the price paid by domestic users. Imported prices should be multiplied by current currency rates including import tariffs.

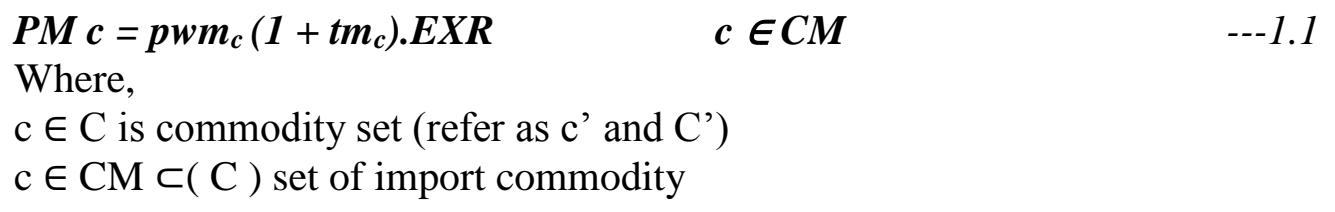


$\mathrm{c} \in \mathrm{CT} \subset(\mathrm{C})$ set of domestic input trade

\section{Export Price}

Export prices are the prices received by domestic manufacturers when they sell their goods to overseas markets. The export price displayed must be equal to the price converted into foreign exchange and excluding export subsidies.

$P E_{c}=p_{w e} \cdot\left(1-t e_{c}\right) \cdot E X R \quad \quad c \in C E$

where,

$\mathrm{c} \in \mathrm{CE} \subset(\mathrm{C})$ set of export commodity (domestic production)

\section{Price of Domestic Demand- Non-trade Goods}

Prices received by consumers and manufacturers must be equal to the demand and price quotes.
$P D D c=P D S c$
$c \in C D$
$---1.3$

Where,

$c \in \mathrm{CD} \subset(\mathrm{C})$ set of commodities with domestic sales by domestic production.

\section{Absorption}

Absorption (on the left) is the amount of domestic spending on commodity prices by domestic users. The price will be the same as the price of domestic suppliers and excluding sales tax. Absorption (on the right) is the sum of domestic and import value.

$P Q c \cdot() 1-t q c \cdot Q Q c=P D D c Q Q D c+P M c \cdot Q M c \quad c \in(C D j C M)--1.4$

Where,

tq $c=$ leakage of $\mathrm{c} *$ STATGST $\mathrm{c}+$ tExcise $\mathrm{c}+$ tproduct $\mathrm{c}$

\section{Output Market Value}

The value of marketed production is the total value of domestic production sold locally and export value.

$P X c \cdot Q X c=P D S c \cdot Q D c+P E c \cdot Q e c \quad c \in C X$

Where,

$\mathrm{c} \in \mathrm{CX} \subset(\mathrm{C})$ set of a commodity with domestic output

\section{Price of Activity}

The activity price is a product per unit of activity and the return on sale sells output from the activity. The activity price is calculated by multiplying 
the yield rate for each output activity with the specific commodity price from the activity.

$\begin{array}{ll}P A c=\sum P X A C a c \cdot \theta a c & a \in A\end{array}$

Price of Aggregate intermediate Input
PINTA a $=\sum P Q c \cdot$ ica ca
$a \in A$
$--1.7$

$c \in C$ Prices for intermediate inputs is the aggregate cost of intermediate inputs fraction per unit of aggregated intermediate input. Prices of aggregated intermediate input are from special activities. While the quantity is the commodity for each aggregated intermediate input unit will be identified as the intermediate input coefficient.

Cost and activity Revenue

Value of revenue from activity (net tax) must equal the value of valueadded payment and intermediate input.

$P A_{a} \cdot\left(1-t a_{a}\right) \cdot Q A a=P V A_{a} \cdot Q V A a+$ PINTA $_{a} \cdot$ QINTA $_{a} \quad a \in A--1.8$

\section{Consumer Price Index}

Consumer price are changeable and DPI function is numeraire.

$C P I=\sum_{c e C} P Q c \cdot c w t s c$

\section{Production And Trade Block}

CES technology: Production Activity Function

QA $a=a_{a}^{a} \cdot\left(\delta_{a}^{a} \cdot Q_{V A_{a}} \mathrm{p}_{a}^{\alpha}+\left(1-\delta_{a}^{a}\right) \cdot Q_{I N T A_{a}}{ }^{-p_{a}^{\alpha}}\right)^{-1 /} \rho_{a}^{a} \in A C E S \quad---2.1$

Where,

$a \in A C E S \subset(A)$ set of activities with CES functionality that is at the top of the production process technology. Production by activity at this level is assuming the goal of maximizing profits subject to existing technology. This function is suitable for value-added and intermediate input activities. The exponential function $\rho$ is the transformation elasticity of the added value and mid-aggregate input aggregate.

ES technology: Value Added of Intermediate Inputs -Input Ratio $Q_{V A} /$ QINTA $_{a}=\left(\text { PINTA }_{a} / P V A_{a} \cdot \delta_{a}^{a} / 1-\delta_{a}^{a}\right)^{1 / 1+} \rho_{a}^{a} \in A C E S$

The determination of optimum mixed intermediate inputs and valueadded as a relative function in the price of intermediate input and value added. 
Value Added and Factor Demand

$Q V A_{a}=\alpha_{a}^{v a} \cdot\left(\sum_{f \in F} \delta_{f a}^{v a} \cdot Q F_{f a}^{-\rho_{a}^{v a}}\right)^{-1 /} \rho_{a}^{v a} \quad a \in A f \in F \quad---2.3$

Where,

$\mathrm{f} \in \mathrm{F}$ set of Faktor (F')

Value-added quantities are when the CES function breaks down by the group on the number of factors. $\mathrm{P}$ equation is the elasticity of replacement factor transformation.

Factor Demand

$W_{f} \cdot$ WFDISTfa $=P V A_{a} \cdot\left(1-t v a_{a}\right) \cdot Q V A_{a} \cdot\left(\sum_{f \in F} \delta_{f a}^{v a} \cdot Q F_{f a}^{-\rho_{a}^{v a}}\right)^{-1} \cdot$ $\left.\delta_{f a}^{v a} \cdot Q F_{f a}^{-\rho_{a}^{v a}}\right) \quad a \in A, f \in F \quad--2.4$

The demand for factors will occur when the marginal cost of each factor is equal to the marginal product of the factor. Marginal cost is defined (on the left) as the price of a specific activity factor. Whereas the marginal product is defined (on the right) less intermediate input costs. the factor price is the dependent variable, while the variable pay variables are independent variables.

The demand for Aggregated intermediate input
QINT $_{c a}=$ ica $_{c a} \cdot Q_{\text {INTA }}$
$a \in A, c \in C$
$---2.5$

For each activity, requests for aggregated intermediate input will be determined by Leontief's standard function. The demand for aggregated intermediate input must be equal to the intermediate input rate used multiplied by the fixed coefficient of intermediate inputs.

\section{Commodity Production and Distribution}

$\boldsymbol{Q X A C _ { a c }}=\theta_{a c} \cdot \boldsymbol{Q A}_{a}$

$$
a \in A, c \in C, h \in H \quad---2.6
$$

Where,

$\mathrm{h} \in \mathrm{H}$ set of household

On the right, production quantities are defined as a result multiplied by activity levels. While on the left, quantities are distributed to enter the market.

Aggregate Output Function

$$
Q X_{c}=a_{c}^{a c}\left(\sum_{a \in A} \delta_{f a c}^{a c} \cdot Q X A C_{a c}^{-\rho_{c}^{a c}}\right)^{-1 /} \rho_{c}^{a c}-1 \quad c \in C X \quad---2.7
$$

The aggregate production of commodities is defined as the CES aggregate of different activities to produce the commodity. The exponential function $\rho$ determines the level of replacement between different products.

Output Transformation Function-(CET) 


$$
Q X_{c=} \boldsymbol{\alpha}_{c}^{t} \cdot\left(\delta_{c}^{t} Q E_{c}^{p_{c}^{t}}+\left(1-Q D_{c}^{\rho_{c}^{t}}\right)^{1 /} \rho_{c}^{t} \quad \quad c \in(\mathrm{CE} \cap \mathrm{CD}) \quad---2.8\right.
$$

Domestic production is produced to meet domestic sales and export markets. The CET function is determined by both domestic exports and sales. The CET function is the same as the CES function except for the negative elasticity of the replacement. Coefficient $\rho$ is the transformation elasticity of elasticity between exports and domestic sales. This shows the perfect replacement assumption between the two destinations.

\section{Composite Supply Function(Armington)}

$$
Q Q_{c}=\alpha_{c}^{q} \cdot\left(\delta_{c}^{q} \cdot Q M_{c}^{-\rho_{c}^{q}}+\left(1-\delta_{c}^{q}\right) \cdot Q D_{c}^{-\rho_{c}^{q}}\right)^{-1 /} \rho_{c}^{q} \quad \mathrm{c} \in(\mathrm{CE} \cap \mathrm{CD}) \quad---2.9
$$

This function is called the Armington function and is a CES function. this function determines the supply of composites as a function of imports and domestic supplies. Assume imperfect replacement effect between imports and domestic supply takes place. The substitution elasticity is set by $\rho$.

\section{Import Demand Ratio-Domestic}

$$
\left(\begin{array}{l}
Q M_{c} \\
Q D_{c}
\end{array}=\frac{P D D_{c}}{P M_{c}} \cdot \frac{\delta_{c}^{q}}{1-\delta_{c}^{q}}\right) \quad c \in(C M \cap C D)
$$

This equation is derived by minimizing costs to the CES function and determining the quantity of composite supply. This is the optimal mix between import and domestic supply. The import-domestic price ratio determines the ratio of domestic import demand.

\section{Institution Block}

Factor Income

$Y F_{f}=\sum_{a \in A} W F_{f} \cdot W_{F D I S T} \cdot Q F_{f a}$

Where,

$Y F f=$ Income of Factor $\mathrm{f}$

This equation defines the amount of revenue for each factor must be equal to the amount of activity payment.

Factor Income for Institution

$Y I F_{i f}=$ shif $_{i f} \cdot\left[\left(1-t f_{f}\right) \cdot Y F_{f}-t_{\text {trnsfr }}\right.$ rowf $\left.\cdot E X R\right] \quad \mathrm{i} \in I N S D, f \in F--3.2$

Where,

$i \in$ INS set of institutions - Domestic and Rest of World (ROW)

$i \in \operatorname{INSD} \subset($ INS $)$ set of domestic institutions 
Total factor income is split between local institutions in a fixed part after direct tax payment on factors and transfers abroad. Transfers converted into domestic currencies by multiplying by exchange rates.

Domestic Income, Non-Government Institutions

$Y I_{i}=\sum_{f \in F} Y I F_{i f}+\sum_{i r \in I N S D N G} T R I I_{i i}+$ trnsfrigov $\cdot C P I+\overline{t r n s f r}_{i r o w} \cdot E X R$

\section{$i \in I N S D N G$ is set of non-government domestic institutions}

Where,

Total non-government institution income is equal to factor income, transfers from other institutions. Transfers from around the world are converted into domestic currencies by multiplying by exchange rates.

\section{Transfer Between Institutions}

TRII $_{i i}$, = shii sii $^{\prime} \cdot\left(1-\operatorname{MPS}_{i},\right) \cdot\left(1-\operatorname{TINS}_{i}\right) \cdot$ Yii $_{i}$,

$i \in I N S D N G, i^{\prime} \in I N S D N G{ }^{\prime}$

Transfers between non-government institutions are paid as part of the net income of direct and depositary institutions.

Household Expenditure

$\mathbf{E H}_{\mathrm{h}}=\left(1-\sum_{i \in I N S D N G} S_{h i i i_{h}}\right) \cdot\left(1-\mathrm{MPSh}_{\mathrm{h}}\right) \cdot\left(1-\right.$ TINS $\left._{h}\right) \cdot Y_{\mathrm{h}} \quad \mathrm{h} \in \mathrm{H} \quad---3.5$

Where,

$\mathrm{h} \in \mathrm{H} \subset($ INSDNG ) set of household

The total value of consumption expenditure by the household must be equal to income tax, savings and transfers between other institutions. Households are also institutions.

Household Expenditure on Commodity Market

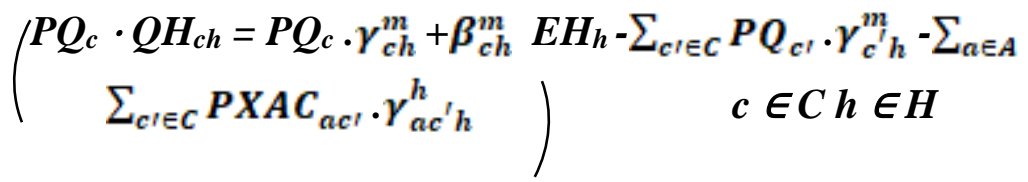

This equation was selected by maximizing the subject of utility functions for use with limited spending constraints. This function is the LES function as commodity expense is a linear function of the amount of expenditure.

Investment Demand

$Q I N V_{c}=\overline{I A D J} \cdot \overline{\text { qinv }_{c}} \quad \boldsymbol{c} \in \boldsymbol{C}$

Fixed investment demand is defined as the quantity in the base year multiplied by an adjustment factor.

\section{Demand by Government}




$$
\boldsymbol{Q G _ { c }}=\overline{\boldsymbol{G A D J}} \cdot \overline{\mathbf{q g}_{\boldsymbol{c}}} \quad \boldsymbol{c} \in \boldsymbol{C}
$$

Government consumption demand is defined as quantities in the base year multiplied by the adjustment factor. Assuming the adjustment factor is exogenous then the quantity in government use is fixed.

Government Revenue

$Y G=\sum T I N S_{i} \cdot Y I_{i}+\sum t f f \cdot Y F_{f}+\sum t v a_{a} \cdot P V A_{a} \cdot Q V A_{a}+\sum_{a \in A} P A_{a} \cdot Q A_{a}+$

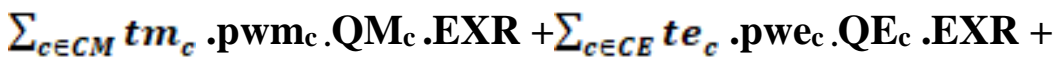
$\Sigma_{c \in c} t q_{c} \cdot \mathbf{P Q c} \cdot \mathbf{Q Q}+\sum_{f \in F} Y F_{\text {govf }}+$ trnsfrgovrow $\cdot \mathbf{E X R}$

Where,

tq $c=$ leakage of $\mathrm{c} *$ STATGST $\mathrm{c}+$ texcise $\mathrm{c}+$ tproduct $\mathrm{c}$

Total government revenue is the sum of revenue from taxes, factors and transfers from overseas transactions. Taxes include direct taxes from institutions, taxes on goods, taxes on activities and import tariffs. Tax on commodities including GST, excise duty and other taxes on products. Transfers will be converted into domestic currencies by multiplying by exchange rates.

Government Expenditure

$E G=\sum_{c \in C} P Q_{c} \cdot Q G_{c}+\sum_{i \in I N S D N G} \operatorname{trnf} s_{i g o v} \cdot \overline{C P I} \quad c \in \mathrm{C} \quad$---3.10

Government spending is the sum of the government's consumption of goods and outgoing transfers.

4. System Constraints Block

Factor Market

$\sum_{a \in A} Q F_{f a}=\overline{Q F S}_{f} \quad f \in F \quad$---4.1

This equation equals the quantity of demand factor and the quantity supplied for each factor.

Composite Commodity Market

$Q Q_{c}=\sum_{a \in A} Q I N T_{c a}+\sum_{h \in H} Q H_{c h}+Q G_{c}+Q I N V_{c}+q d s t c \in C$

This equation is the balance between quantity demand and the supply of composite commodities. The demand side includes demand for intermediate goods, demand for household consumption, government consumption, investment, and change in stocks. government use, investment demand and stock changes are determined as independent variables. The composite supply determines the demand for domestic and imported sales.

The balance of Current Accounts for Foreign Transactions (in foreign exchange) 


\section{$\sum_{c \in C M} P w m_{c} \cdot Q M_{c}+\sum_{i \in I N S D}$ trnsfrrowf $=\sum_{c E C E} P w e_{c} \cdot Q E_{c}+\sum_{i \in I N S D}$ trnsfrirow $+F S A V$

The balance in the current account will occur when there is an equality between total expenditure and income from foreign exchange. The designated closure is a flexible exchange rate and foreign savings are fixed.

\section{Government Balance}

For government accounts, the typical specification is government spending is fixed at actual prices; government revenue is determined by fixed tax rates; and government savings as a gap between income and expenditure. Therefore government savings may be negative in government equality $Y G=E G+G S A V$

In this analysis, the balance of government is an important part of the simulation. In all the simulations, it is assumed that government saving (GSAV) is a fixed tax and direct domestic tax and the rates set in uniform to maintain the state's balance. This means that the direct tax rate will be adjusted according to the requirements and coincides with the increased revenue generated from GST renewal. This assumption is to measure or assess the welfare effects of the middle-income group during the implementation of GST.

\section{Saving-Investment Balance}

The usual way to create a savings-investment account in the CGE model is by combining savings and investment. This account collects total deposits and purchases on investment items. In doing so, the new flow balance is added to the model. This requires the flow of deposits made equal to the flow demand for investment goods as shown in the equation below;

$\sum_{i \in I N S D N G} M P S_{i} \cdot\left(1-T_{T N S}\right) \cdot Y I_{i}+G S A V+E X R \cdot F S A V=\sum_{c E C} P Q_{c} \cdot$ $Q I N V_{c}+\sum_{c \in C} P Q_{c} \cdot q d s t$

where MPS is a marginal propensity to store by the institution, QINV is the number of fixed investment commodities. Changes in capital stock are not in this model. Equation (4.7) states that the amount of savings is the amount of savings from government and foreign transactions. A mechanism is introduced to achieve the balance of investment savings. The savings rate, MPS, by the institution is the key to this mechanism. It can be stated as fixed so that what is stored is then spent on investment. Therefore we assume that savings will lead to investment.

Total Absorption

TABS $=\sum_{h \in H} \sum_{c \in C} P Q_{c} \cdot Q H_{c h}+\sum_{a \in A} \sum_{c \in C} \sum_{h \in H} P X A C_{a c} \quad Q H A A_{a c h}+$ $\sum_{c \in C} P Q_{\varepsilon} \cdot \mathbf{Q G} \mathrm{G}+\sum_{c \in C} P Q_{\varepsilon} \cdot \mathbf{Q I N V}_{\mathrm{c}}+\sum_{c \in C} P Q_{\varepsilon} \cdot \mathbf{q d s t _ { c }}$ $---4.8$ 
The amount of absorption is the total amount of domestic end-ofdemand. GDP will be balanced at market prices when total imports decrease export volume.

\section{Investment Absorption Ratio}

INVSHR .TABS $=\sum_{c \in C} P Q_{c} \cdot Q I N V_{c}+\sum_{c \in C} P Q_{c} \cdot q d s t_{c}$

To the right of the equation is the total value of the investment. Total investment value is calculated as a proportion of the nominal absorption multiplied by total absorption. Then the amount of investment is equal to the value of the investment demand and the value of the change in stock.

\section{Government Consumption Ratio for Absorption}

GOVSHR .TABS $=\Sigma_{c \in C} P Q_{c} \cdot Q G_{c}$

To the right of the equation is the value of government use. The value of government consumption is calculated as part of the nominal absorption multiplied by total absorption.

\section{Model Closures}

In achieving a general balance, it is a requirement to state the closures in the macro aggregate level. In the CGE model, there are three macroeconomic equations, namely external balance accounts (current account and trade balance), investment accounts and government accounts. The closures that need to be in this balance have been selected to reflect the Malaysian economic environment.

To represent the labour market in Malaysia, we assume capital and highskilled labour are fully employed and activity-specific, while semi-skilled and low-skilled labour is unemployed and mobile. For capital and high-skilled labour total employment will not change, only the factor payment, which is activity-specific, will change. For semi- and unskilled labour nominal wages will remain constant as these factors experience high levels of unemployment. The only factor that would change for semi- and unskilled labour is employment.

The balance in the current account will occur when there is an equality between total expenditure and income from foreign exchange. The designated closure is a flexible exchange rate and foreign savings are fixed.

For the savings-driven investment, the closure will be used for the simulations. The level of savings determines investment. In a report by BNM (2014), it is found that Malaysia's savings-investment surplus has been driven mainly by the private sector, which has constantly registered an excess of savings over investment in the last decade. The high level of savings by the corporate sector and households is attributable to two main factors. First, 
corporate profits have increased following sustained external demand for resource-based products, especially prior to the Gross Fixed Capital (GFC). Second, mandatory contributions to the Employee Provident Fund, coupled with sustained wage growth, have supported household savings. This implies that the savings level will determine investment. It is for this reason the savings-driven closure is chosen for the simulations.

The last closure to be considered is that of the government balance. When we analyse using simulations by removing the GST and increasing the income tax rate, the level of government savings will be fixed and direct taxes will be scaled to absorb the loss in revenue due to the removal of GST.

\section{Efficiency Of GST}

To measure the efficiency of GST, the commonly used method is through 'efficiency ratio' (E) and 'C-efficiency ratio' as done by Keen \& Lockwood (2010). 'Efficiency ratio' (E) is defined as a share of GST in GDP divided by the standard GST rate. For example, if E is 30 per cent and the assumed GST rate increases to 1 per cent then GDP revenue is expected to increase to 0.3 per cent. However, using this method is not quite accurate and is quite confusing as it is based solely on the gross amount of GDP alone without taking into account the exception factor and zero tax in GST. Therefore, the more appropriate measurement method is through the C-Efficiency Ratio (CE).

'C-efficiency ratio' (CE) is defined as GST revenue in household expenditure divided by the standard GST rate of 6 per cent. These measurements emphasize more on the outcome of household spending as compared to GDP in E.

\section{Instrument Measurement Of GST Impacts On Welfare}

Through the CGE model, the impact on the household will be taken into account. Therefore, many economic variables are included in this model to see the impact of GST. Changes in these variables will be observed or analysed through simulation analysis. In addition, issues such as regressive or progressive levels of GST and change in welfare should also be addressed through this study to answer the research questions.

a. Regressive

Measurement to the regressive level is to take into account household expenditure on GST (percentage of expenditure on GST from total income). Total expenditure on GST for each household category is calculated in the following CGE model;

$$
\text { Regressive }(h)=\frac{\Sigma Q H(c, i) * H Q(c) * G S T r a t e}{\mathrm{YI}(\mathrm{i})}
$$


Where;

Regressive ( $h$ ) the measurement of regressivity level in GST for each household

$Q H(c, h) \quad$ the quantity of commodity $c$ consumed by household $h$

$H Q(c) \quad$ the price of commodity $c$

GST rate the rate of GST on commodity $c$

$Y I(h) \quad$ the total income of household $h$

b. Progressive

The progressivity of the complete tax system is measured by taking the total payment of taxes by each household as a percentage of total income (Kearney, 2003).

Progressive $(h)=\frac{\Sigma Q H(c, h) * P Q(c) * \operatorname{tgst}+\operatorname{texcise}(c)+\operatorname{tproducts}(c)+\operatorname{tins}(h) * Y I(h)}{Y I(h)}$

Where;

Progressive ( $h$ ) measures the progressiveness of VAT for each household $\mathrm{h}$

$Q H(c) \quad$ the quantity of commodity c consumed by household

$\mathrm{h}$

$P Q$ (c) the average output price of commodity c

Tgst the actual VAT rate paid on commodity c

$\operatorname{tins}(h) \quad$ the marginal tax rate of household $\mathrm{h}$

$Y I(h) \quad$ the total income of household $\mathrm{h}$

c. Equivalent Variation

To find the welfare effect of taxation, the EV equation is used. This method is more commonly used as a measure of welfare than other indicators in taxation that was proposed by Hicks in the year 1939 (Alston \& Larson, 1993). According to their study, the definition of this equation is to assess the difference in value that occurs in the price before and after the price change. $\mathrm{EV}$ equations are written as follows;

$\mathrm{EV}=\left(\mathrm{U}^{\mathrm{N}}, \mathrm{P}^{0}\right)-\mathrm{E}\left(\mathrm{U}^{0}, \mathrm{P}^{0}\right)$

The EV equation can also be used to find the welfare effect of each household category. Fullerton et al. (1983) also used this equation in the study of changes in taxation and international trade policy. Then they modified this equation into a simpler form;

$\mathrm{EV}=\frac{U N-U_{0}}{U_{0}} \cdot I^{0}$

with,

$\mathrm{U}(\mathrm{h})=\sum_{i}\left(a_{i}^{h}\right) \frac{1}{\sigma h} .\left[\left(X_{i}^{h}\right) \frac{\sigma h-1}{\sigma h}\right] \frac{\sigma h}{\sigma h-1}$ 
where;

EV is Equivalent Variation

$U$ is utility level

$N$ is utility level after implementation of GST

$O$ is utility level before implementation of GST

$O I$ is income level before GST

Hiai is share parameter for goods $\mathrm{i}$ by household $\mathrm{h}$

$h i X$ is quantity goods i demands by household $\mathrm{h}$

$h \sigma$ is the elasticity of substitution by household $h$

d. Simulations

In the simulation process of the CGE model, three scenarios were made in the impact assessment of GST implementation in looking at the impact on government revenue and welfare for the lower income group.

Scenario 1: The GST rate is reduced to four per cent and there is an increase in the M40 and T20 direct income tax rate by $10 \%$ and $28 \%$ 
Scenario 2: The GST rate is maintained at six per cent and the implementation of zero rates and tax exemption on expanded food items only.

Scenario 3: a Tax rate of GST is abolished and back to the normal rate of Sales and Services Tax (SST) at 10\% on goods and $6 \%$ on services.

Table 1. Malaysian Macro SAM 2014 (MYSAM)

\begin{tabular}{|c|c|c|c|c|c|c|c|c|c|c|c|c|c|}
\hline & no & 1 & 2 & 3 & 4 & 5 & 6 & 7 & 8 & 9 & 10 & 11 & 12 \\
\hline no & RM (Billion) & Activities & Commodities & Factors & Household & Company & Government & S_I & Banking & $\begin{array}{l}\text { ROW- } \\
\text { current }\end{array}$ & $\begin{array}{l}\text { ROW- } \\
\text { capital }\end{array}$ & $\begin{array}{c}\text { Indirect } \\
\text { Tax }\end{array}$ & Total \\
\hline 1 & Activities & & 2358.2 & & & & & & & & & & 2358.2 \\
\hline 2 & Commodities & 1285.5 & & & 532.2 & & 146.5 & 169.5 & & 637.5 & & & 2771.2 \\
\hline 3 & Factors & 1072.8 & & & & & & & & 53 & & & 1125.8 \\
\hline 4 & Household & & & 461.6 & 2.9 & 92.6 & 54.2 & & 27.5 & 0.04 & & & 638.84 \\
\hline 5 & Company & & & 574.7 & & 35.2 & & & 48.6 & 8 & & & 666.5 \\
\hline 6 & Government & & & & 17.4 & 107.1 & & & 39.5 & 0.3 & & 42.4 & 206.7 \\
\hline 7 & S_I & & & & 5.9 & 312.4 & 4.5 & & & & & & 322.8 \\
\hline 8 & Banking & & & & & 115.6 & & & & & & & 115.6 \\
\hline 9 & ROW-current & & 401.1 & 89.5 & 63.2 & 3.5 & 1.5 & 99 & & & 102.6 & & 760.4 \\
\hline
\end{tabular}


Kompartemen: Jurnal Ilmiah Akuntansi/September 2018, XVII(2), 124-146

\begin{tabular}{|c|c|c|c|c|c|c|c|c|c|c|c|c|c|}
\hline 10 & ROW-capital & & & & & & & 46.3 & & 56.3 & & & 102.6 \\
\hline 11 & Indirect Tax & & 11.9 & & 17.2 & & & 8 & & 5.3 & & & 42.4 \\
\hline 12 & Total & 2358.3 & 2771.2 & 1125.8 & 638.8 & 666.4 & 206.7 & 322.8 & 115.6 & 760.44 & 102.6 & 42.4 & \\
\hline
\end{tabular}

Source: Author's calculation based on Malaysian SAM 2014 by DOS 


\section{CONCLUSION}

The government's move towards implementing GST is an excellent step in raising government revenue thus reducing the country's deficit rate and improving the existing tax system. Although the idea of implementing GST has been considered for a long time and the government has delayed its implementation because the government wanted the good preparation and people's readiness to be taken into account.

Various issues arise from GST. Therefore, the study of this issue should be carried out using a CGE model to achieve the objective of the study. CGE is a great way to examine the impact of GST tax changes in our country as it calculates many of the factors related to the economy.

The standard model of Lofgren et al. (2001) is used as a guide to analysing the effects of GST implementation on government revenue and households of (M40) and (B40). This model consists of a set of equations from Neoclassical. The purpose of the breakdown of categories or groups of households is in accordance with the objectives of the study.

In the steps of building a CGE model, the SAM schedule is required as one of the key input components. Households will be broken into three income groups, high (T20), moderate (M40) and low (B40) as well as urban and rural areas. Using the SAM table, which has an overview of the overall economic structure of the CGE model, makes this model more realistic. In addition, the elasticity factor of the CES equation is calibrated to make this model balanced.

A balanced CGE model may change when running the simulation process. Any changes from the simulation will be analysed. To find out the impact of GST, the instrument to measure the impact of GST on government revenue is through the calculation of C-efficiency ratio (CE). While the impact on the welfare of the middle- and low-income groups is through the regressive and progressive system and the overall impact on welfare through the calculation of the equivalent variant $(\mathrm{EV})$.

The CGE utilized in the present study can be applied to answer questions concerning whether GST implementation would have the trade-off between government revenue and the targeted groups by taking into account the elements of GST such as standard-rate, zero-rate and exempted rate. Based on the proposed framework of model review, the instruments used for measurement of effectiveness and welfare were C-efficiency ratio, regressive, progressive, equivalent variation and simulations. The paper will give an opportunity for future research work in the related area. 


\section{ACKNOWLEDGEMENT}

The author would like to acknowledge the support from the Fundamental

Research Grant Scheme (FRGS) under a grant number of FRGS/1/2017/SS03/UNIMAP/03/1 from Ministry of Higher Education Malaysia.

\section{REFERENCES}

Acharya, S. (2016). Reforming value-added tax system in the developing world: the case of Nepal. Business and Management Studies, 2(2), 44-63. http://doi.org/10.11114/bms.v2i2.1616

Alston, J. M., \& Larson, D. M. (1993). Hicksian vs. Marshallian welfare measures: why do we do what we do? American Journal of Agricultural Economics, 75(3), 764-769. http://doi.org/10.2307/1243588

Avitsland, T., \& Aasness, J. (2004). Combining CGE and microsimulation models : Effects on equality of VAT reforms, (392).

BNM. (2014). Annual report 2014.

Brendon, C. (2013). Efficiency, equity, and optimal income taxation. Job Market Paper, (November), 1-52.

Bye, B., Strøm, B., \& Åvitsland, T. (2003). Welfare effect of VAT reforms: a general equilibrium analysis. International Tax and Public Finance, (343).

Devarajan, S., J.D., L., Go, D. S., Robinson, S., \& Sinko, P. (1997). Simple general equilibrium modelling. Applied Methods for Trade Policy Analysis, $156-185$.

Devarajan, S., \& Robinson, S. (2002). The Impact of computable general equilibrium models on policy. Frontiers in Applied General Equilibrium Modeling, (May), 1-21. http://doi.org/10.1017/CBO9780511614330.016

Erero, J. L. (2015). Effects of increases in value-added tax: a dynamic cge approach effects of increases in value-added tax: a dynamic cge approach, (November).

Fullerton, D., Shoven, J. B., \& Whalley, J. (1983). Replacing the U.S. income tax with a progressive consumption tax. A sequenced general equilibrium approach. Journal of Public Economics, 20(1), 3-23. http://doi.org/10.1016/0047-2727(83)90018-X 
Gale, W. G., \& Rohaly, J. (2002). Effects of tax simplification options on equity, efficiency, and simplicity: a quantitative analysis. Conference on Crisis in Tax Administration Local: Brookings Inst, Washington, DC Data: NOV 07 08, 2002. Retrieved from http://citeseerx.ist.psu.edu/viewdoc/download? doi=10.1.1.563.1449\&rep=rep1\&type=pdf

Giesecke, J. A., \& Tran, N. H. (2009). Modelling value-added tax in the presence of multiproduction and differentiated exemptions, (44017).

Go, D. S., Bank, W., Kearney, M., Africa, S., Treasury, N., Robinson, S., Academy, U. S. N. (2005). An analysis of South Africa's value-added tax.

Hassan, A. A. G., Saari, M. Y., Utit, C., Hassan, A., \& Mukaramah-Harun. (2016). Penganggaran impak pelaksanaan cbp ke atas kos pengeluaran dan kos sara hidup di Malaysia. Jurnal Ekonomi Malaysia, 50(2), 15-30. http://doi.org/10.17576/JEM-2016-5001-02

Kearney, M. (2003). Restructuring value added tax in South Africa: a computable general equilibrium analysis. University of Pretoria.

Keen, M., \& Lockwood, B. (2010). The value-added tax: Its causes and consequences. Journal of Development Economics, 92(2), 138-151. http://doi.org/10.1016/j.jdeveco.2009.01.012

Levin, J., \& Sayeed, Y. (2014). Welfare impact of broadening VAT by exempting local food markets: The case of Bangladesh, 0-24. Retrieved from https://www.oru.se/globalassets/orusv/institutioner/hh/workingpapers/workingpapers2014/wp-7-2014.pdf

Lledo, V. D. (2005). Tax systems under fiscal adjustment : a dynamic cge analysis of the Brazilian tax reform, 33.

Lofgren, H., Thomas, M., \& El-said, M. (2002). A standard computable general equilibrium (cge) model in gams.

NCAER. (2009). Moving to goods and Services Tax in India : impact on India 's growth and international trade.

Okyere, E., \& Bhattarai, R. K. (2005). Welfare and growth impacts of taxes : applied general equilibrium models of Ghana, (August), 1-33.

Prof, B. Y., \& Ajakaiye, O. (1999). Macroeconomic effects of VAT in Nigeria : A computable general equilibrium analysis. The African Economic Research Consortium. 
Rege, S. R. (2002). A general equilibrium analysis of VAT in India. Review of Urban and Regional Development Studies, 14(2), 153-188. http://doi.org/10.1111/1467-940X.00053

Saira, A., Ahmed, V., \& Ahsan, A. (2010). Taxation Reforms: A CGE microsimulation analysis for Pakistan.

Sajadifar, S. H., Khiabani, N., \& Arakelyan, A. (2012). A computable general equilibrium model for evaluating the effects of value-added tax reform in Iran. World Applied Sciences Journal, 18(7), 918-924. http://doi.org/10.5829/idosi.wasj.2012.18.07.1772

Tamaoka, M. (1994). Tax: Tax credit method and subtraction method - a Japanese case. Fiscal Studies, 15(2), 57-73.

Unit Perancang Ekonomi. (2015). Rancangan Malaysia Ke-11 (2016-2020). Unit Perancang Ekonomi, Jabatan Perdana Menteri. Retrieved from http://www.epu.gov.myAmerican Psychological Association. 2001. Publications Manual of the American Psychological Association (5th ed.) Washington, D. C.: American Psychological Association.

Feldman, D. C. 2004. The devil is in the details: Converting good research into publishable articles. Journal of Management, 30(1): 1-6.

Leedy, P. D., and J. E. Omrod. 2005. Practical Research: Planning and Design (8th ed.). Upper Saddle River, New Jersey: Merril Prentice Hall.

Perry, C., D. Carson, and A. Gilmore. 2003. Joining the conversation: Writing for EJM's editors, reviewers and readers requires planning, care and persistence. European Journal of Marketing, 37(5/6): 653-557.

Summers, J. O. 2001. Guideline for conducting research and publishing in marketing: From conceptualization through the review process. Journal of the Academy of Marketing Science, 29(4): 405-415. 
Appendix- Note of Mathematical Equations

The dependent variable - upper case Latin without bar lines

An independent variable / Exogenous - upper-case Latin with bar lines

Latin letters (with a line bar or none or lowercase Greek (there are superscripts or not)

Set the Latin lower case index as a subscript for the variable and Parameter

Set

A set of activities

ACES (in A) Activity set with CES functionality that is above the nest technology

C Set of commodities

$\mathrm{CD}$ (found in C) Commodity set (domestic sales from domestic output)

CDN (found in C) Commodity set without domestic market sales of domestic output (CD)

$\mathrm{CE}$ (found in $\mathrm{C}$ ) Export commodity set (domestic production)

CEN (found in C) Non-export commodity set (complementary to CE)

$\mathrm{CM}$ (found in C) Import commodity set

CMN (found in C) A non-import commodity set

CX (found in C) Set of commodities with domestic output

Set $F$ (set of a factor)

FLAB Set Labor category

H Set a household

INS Institutional set (domestic or ROW)

INSD Set of domestic institutions

INSDNG Set of domestic non-governmental institutions

Parameter

$\alpha_{a}^{a} \quad$ parameter of efficiency in CES function

$\alpha_{c}^{a c} \quad$ Transfer Parameter of aggregate domestic commodity function

$\alpha_{c}^{q} \quad$ CES function with parameter

$\alpha_{c}^{t} \quad$ CET function with parameter

$\alpha_{a}^{v a} \quad$ parameter of efficiency in CES value added

$\beta_{c h}^{m} \quad$ household (h) expenditure on commodity c

$\delta_{a}^{a} \quad$ CES activity function sharing parameter

$\delta_{a c}^{a c}$ Parameter for aggregate domestic commodity function

$\delta_{c}^{q} \quad$ CES function sharing parameter

$\delta_{c}^{t} \quad$ CET function sharing parameter

$\delta_{f a}^{v a}$ CES value-added function sharing parameter of factor $\mathrm{f}$ in activity a

$\rho_{a}^{a} \quad$ CES activity exponential function

$\rho_{c}^{a c}$ exponential function of aggregate domestic commodity 


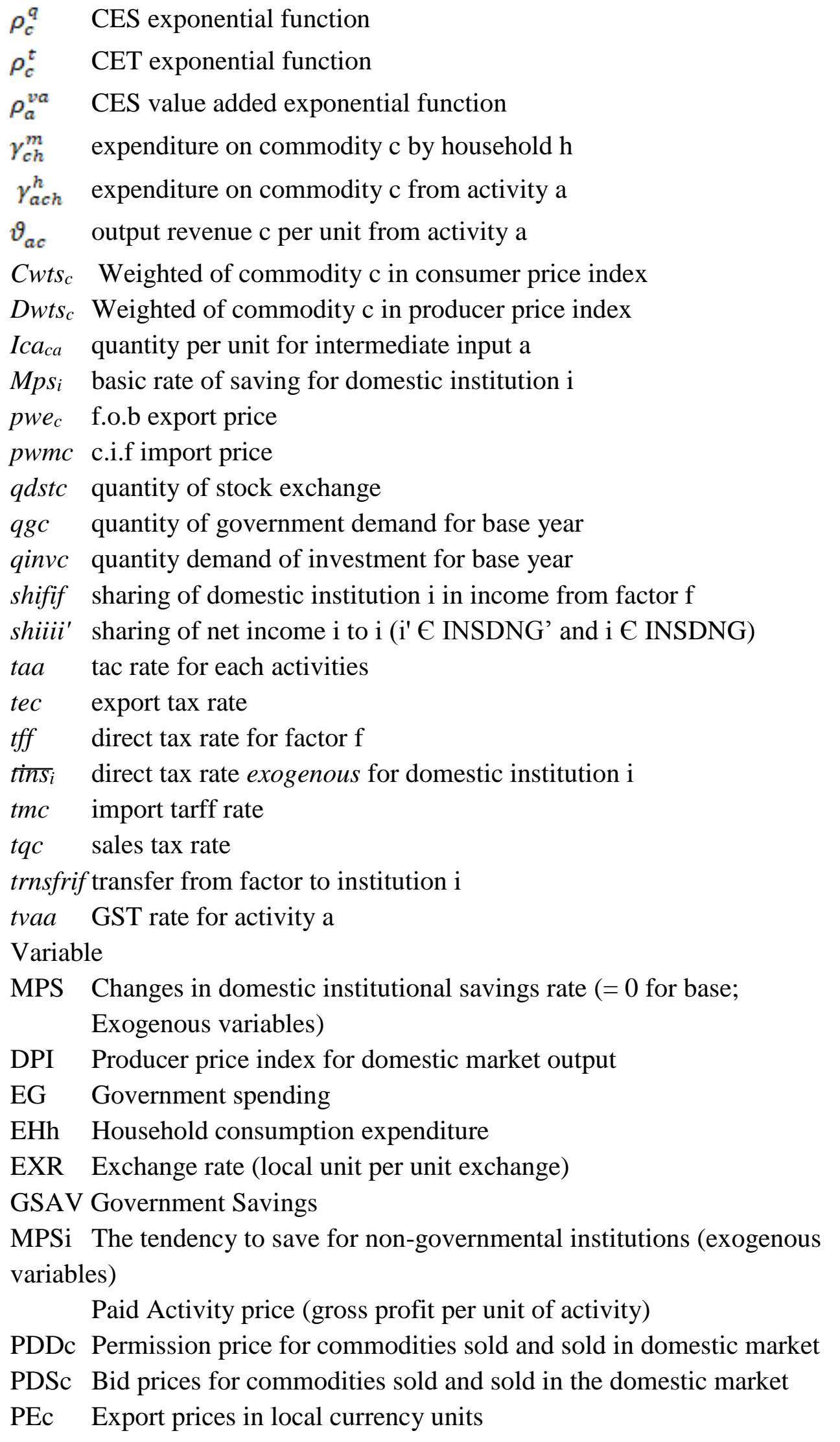


Intermediate aggregate Input Prices for a

PMc Import prices in local currency units

PQc Composite commodity prices (market price)

Price (aggregate) value-added PVAa

PXc Producer aggregate prices for commodities

PXACac Commodity producer price $\mathrm{c}$ for a

QAa Quantity (level) of activity

QDc Quantities sold in the domestic market

QEc Export quantity

QFfa Quantity of demand by factor $\mathrm{f}$ for activity a

QGc Demand for government use for commodities c

QHch Quantity of commodity use c by household h

QINTca Commodity quantity c as an intermediate input in activity a

QINTAa Intermediate input aggregate quantity

QINVc Quantity of fixed investment demand for commodities c

QMc Quantity of imported commodities

QQc Quantity of goods offered to the domestic market (composite supply)

QVAa Quantity (aggregate) value added

QXc Aggregate quantity for the domestic output of commodities

QXACac Quantity of commodity market output c in activity a

TINSi Direct tax rate on domestic institutions $i$

TABS Nominal amount of absorption

TRIIii Transfer from institution i' to i (both in INSDNG set)

WFf Average factor price

YG Government revenue

YIi Institution income i (in INSDNG set)

YIFif Income of domestic institutions from factor $f$

Independent Variables (Exogenous)

CPI Consumer price index (exogenous variables)

DTINS Changes in domestic institutional tax ( $=0$ for basis; exogenous variables)

FSAV Foreign reserves in foreign currency units (exogenous variables)

GADJ Government use adjustment factor (exogenous variables)

IADJ Investment factor adjustment (exogenous variables)

MPSADJ Scale factor storage rate (= 0 for basic)

QFSf Supply quantity by factor $\mathrm{f}$ (exogenous variable)

TINSADJ Direct factor tax (= 0 for basic; exogenous variables)

WFDISTfa distortion in salaries or wages for factor $\mathrm{f}$ in an activity (exogenous variables) 
Kompartemen: Jurnal Ilmiah Akuntansi/September 2018, XVII(2), 124-146 